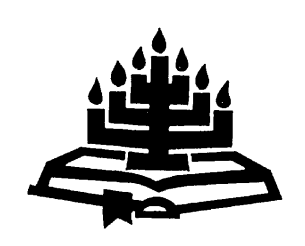

\title{
God's gifts to humankind: a legal- philosophical interpretation of Luther's views on ownership and the natural right to property
}

\author{
A.W.G. Raath \\ Department of Constitutional Law \& Philosophy of Law \\ University of the Free State \\ BLOEMFONTEIN \\ E-mail: raathA.RD@ufs.ac.za
}

\begin{abstract}
God's gifts to humankind: a legal-philosophical interpretation of Luther's views on ownership and the natural right to property

The collapse of the medieval political and social order, the rise of the nation state and the emergent absolutism of civil rulers, meant that the early Reformers had to make a clearer demarcation between the natural right to private property and the moral conditions giving rise to such a right, and a clearer delineation of the duties of civil authorities in dealing with private property in civil society. Luther's view that natural right presupposes the existence of moral duty and is intricately connected with the moral uprightness of the owner's activities, produces a number of important perspectives still relevant for the debate concerning the natural rights of individuals to own property and to have the sphere of liberty attached to this right adequately protected.
\end{abstract}

\section{Opsomming}

God se geskenke aan die mensdom: 'n regsfilosofiese interpretasie van Luther se standpunte oor eienaarskap en die natuurlike reg op eiendom

Die verval van die Middeleeuse politieke en sosiale orde, die verskyning van die nasiestaat en die opkoms van burgerlike regeerders, het die vroeë Reformatore genoodsaak om 'n duideliker afbakening tussen die natuurlike reg op private eiendom en die morele voorwaardes wat tot sodanige reg aanleiding 
gee, te tref in hulle oorweging van die rol van private eiendom in die burgerlike samelewing. Luther se siening dat fundamentele regte die bestaan van morele plig veronderstel en nóú verbind is met die moreel-regskape aard van die eienaar se handelinge, het 'n aantal belangrike perspektiewe opgelewer wat steeds relevant is vir die huidige debat met betrekking tot die fundamentele regte van individue om eiendom te besit en om die vryheidsfeer wat aan hierdie reg verbonde is, voldoende te beskerm.

\section{Introduction}

The rights of human beings are embedded in a moral order of freedom, duty and benevolence. Cicero's statement to the effect that "( $\mathrm{t}$ )he foundation of right is found in the inclination we all possess by nature to love our fellows" (Cicero, 1948: $D L, 1,15)$ produced profound implications for the views of the Reformers on the freedom of man in civil society; for human personhood as the supreme, active principle of man's responsibilities in performing moral and legal acts; the good involved in acting according to the exigencies of human nature; the requirements of lawfulness determining the "goodness" or "evil" of human actions; the moral exigency in human beings not to intrude upon the rights of others; the limitations for the exercise of rights, as well as the correlation between jural right and moral duty in matters pertaining to ownership and the right to private property.

The Reformers' views on the right to property, albeit an extension of the discourse on ownership and the right to private property by the early Church Fathers, contributed substantially towards the development of refined perspectives on the jural right to property within the over-arching view on the moral nature of right expressed by Cicero.

Cicero's phrase, (s)unt autem privata nulla natura, provided the foundation for the distinction between that which is natural and conventional in the domain of ownership, and the right to property in the Medieval period and the era of the Reformation. Although a reformational thinker like Melanchthon did not materially deviate from the Ciceronian view, ${ }^{1}$ earlier views of the Church Fathers differed on this issue. Reformational thinkers like Luther and Calvin, however, took the right to private property to be a natural right within the broad context of jural right and moral obligation - the implications of which

1 Cf. Melanchthon's (1952:44, line $3 \mathrm{ff}$.) observations in his Loci communes of 1521. 
are instructive for the dilemmas often posited by legal and theological authors between naked capitalism (based on the natural right to property) and the proponents of communism and socialism advancing the "natural right" to common property (based on equalitarianism).

\section{Ownership and the right to private property in the works of the early Church Fathers}

\subsection{St. Ambrose on the principle of communal property}

In his De officiis, St. Ambrose (1997:1.28) writes:

But we measure nothing at all but that which is fitting and virtuous, and by that rule of things rather than of things present; and we state nothing to be useful but what will help us to the blessing of the eternal life, certainly not that which will help us enjoy merely the present time. Nor do we recognise any advantages in opportunities and in the wealth of earthly goods, but consider them as disadvantages if not put aside, and to be looked on as a burden, when we have them, rather than as a loss when expended.

St. Ambrose provided a general view on property that entailed that nature produced all things for the common use of all men, that nature provided the common right of property, but that usury leads to the private right to property. In other terms: that God originally created the earth for the common use of all persons, to provide its fruits to the benefit of the entire human race, but that avarice established the private right of ownership (cf. Carlyle, 1913:119-132, at 121).

Although, says St. Ambrose, according to the will of God, the earth should be the common possession of all men, it is just that the person who claims for his private ownership that which is given to the human race in common, should distribute some of this to the poor (Ambrose, 1997:118:8.22). Therefore, to St. Ambrose, charity or almsgiving is an action of injustice, rather than an act of mercy. In essence this means that the person who is in need has a legitimate right to claim for his need that which is to another person a superfluity (cf. Carlyle, 1913:124).

\subsection{St. Thomas Aquinas on ownership and private property}

In his Summa, St. Thomas, distinguishing between the right to property in a natural and in a conventional sense, differentiates be- 
tween property regarded as a right to acquire and distribute, and property to use for oneself. In the first sense, Thomas holds a legitimate individual right in order to prevent

... the constant quarrels among those who hold things in common. However, the second category does not harbour a private right to property, because a person must hold those things which are his for the common use, and he must administer of which he has to the necessities of others (Aquinas, 1997, S.T., $P(2 b)-Q(66)-A(2))$.

St. Thomas's views on the limits to the rights of private property produced three important consequences: firstly, although private property is lawful and not contrary to nature, private rights cannot override the common right of mankind to the necessaries of life; secondly, almsgiving is an action which belongs to love (caritas), although it is also a matter of obligation (in praecepto), because although temporal possessions are private as regards ownership, as regards use they belong to others who have need of them; and thirdly, because human positive law cannot overturn natural and divine law, a man may legitimately take - either openly or by stealth - what he needs, because in the case of extreme necessity, all things are common (Aquinas, 1997, S.T., P(2b)-Q(66)-A(7); P(2b)$\mathrm{Q}(32)-\mathrm{A}(7))$.

\subsection{Clement of Alexandria, Lactantius and Chrysostom on ownership and the natural right to private property}

Among the Church Fathers, Clement of Alexandria, Lactantius and Chrysostom advanced the principle that the natural right to private property can be discerned. In his Stromata, Clement of Alexandria, considering some aspects of the beatitudes, states that "God dispenses to all according to desert" (Clement, 1997:3.6.54 ff.). To Clement God's distribution is righteous. The covetous who are more committed to the love of money, are called lovers of Mammon, "not because of their possessing property, but of their inordinate affection to what they possessed" (Clement, 1997:3.6.54 ff.). No spiritual consolation is to be gained by the avarous love of possessions. Rather man should love God and serve the neighbour in love with his possessions (Clement, 1997:3.6.54 ff.).

In his Divine institutes, Lactantius follows Cicero's observation that originally the whole of creation was given for the benefit of man (Lanctantius, 1997, DI, 5.5). Lactantius proceeds to apply a fine distinction between the common use of property and private owner- 
ship - the one does not exclude the other. God had originally given the earth in common to all, "that they might pass their life in common, not that mad and raging avarice might claim all things for itself, and that that which was produced for all might not be wanting to any" (Lanctantius, 1997, DI, 5.5). This does not suggest that individuals at that time had no private property, but

it must be regarded as a practical figure; that we may understand that men were so liberal that they did not shut up the fruits of the earth produced for them, nor did they in solitude brood over the things stored up, but admitted the poor to share the fruits of their labour (Lanctantius, 1997, DI, 5.5).

In man's state of innocence, God's "storehouse of good liberality lay open to all": also avarice did not intercept the "divine bounty", and thus cause hunger and thirst in common. Those who had possessions gave liberally and bountifully to those who had not (Cicero, 1948, DL, 5.5). After man's fall into sin, human beings lost their sense of piety and their innocence - hatred and envy were introduced among men, "and envy, and stratagem", so that they became as "poisonous as serpents", and "rapacious as wolves" (Cicero, 1948, $D L, 5.5)$.

The source of all these evils was lust. Those who had a superfluity of possessions failed to bestow a share upon others: they even seized the property of others, drawing everything to their private gain; "and the things which formerly even individuals laboured to obtain for the common use of men, were now conveyed to the houses of a few" (Cicero, 1948, DL, 5.5).

Chrysostom (1997), in his Homilies on Matthew, advanced the natural right to property. He cites the example of Ahab's avaricious possessing of Naboth's vineyard to emphasise that it was the desire of his neighbour's goods which caused Ahab's ruin - "although he would have paid a price, yet he took it from one unwilling" (Chrysostom, 1997:1073). Chrysostom admonished that people ought not to buy by force, but on persuasion

... [b]ut if he, who would have paid the fair price, was so punished, because he took from one unwilling, he who doeth not so much as this, and taketh by violence from the unwilling, and that when living under grace, of what punishment will he not be worthy? (Chrysostom, 1997:1073).

In order therefore that we be not punished, keeping ourselves quite pure from all violence and rapine, and guarding against the sources 
of sins "together with the sins themselves", let us "with much diligence give heed to virtue; for thus shall we also enjoy the good things eternal by the grace and love towards man ..." (Chrysostom, 1997:1073-1074).

\section{Martin Luther on moral duty, ownership and the natural right to property}

\subsection{Ownership and the moral context of fundamental right}

Aristotle's rather paradoxical statement, followed by St. Augustine, that "property ought to be common in a sense, but private speaking generally", and his remark that "possessions should be privately owned, but common in use", and in order to train the citizens to this is the special task of the legislator, to a certain extent clouds the boundaries between the legal and moral duties pertaining to private property (cf. Aristotle, 1979, 2.2: 1263 a26, 38-39 and Aquinas, 1997, S.T., $P(2 b)-Q(66)-A(2) ; P(2 b)-Q(32)-A(5))$. It could thus be asked under which circumstances the population acquires the right to demand my property and whether such demands could also include the right to redistribute the property of the rich.

The profound depth of Luther's thought penetrated much further into the reality of human relationships, the phenomenon of human avarice and the duties of civil society in ordering the political implications of property rights in its domain of civil relations, than did the theologico-political efforts of the medievalists. This brought Luther's position on the right to property closer to that of Lactantius than to the doctrine of Aristotelian-Thomist views on these matters.

In order to appreciate the impact of Luther's thought on ownership and the natural right to property, it is important to consider the philosophical implications of his theological perspectives on human beings' relationships to God and their fellow-humans (that which we could call the idea of being), the essence of man (human personhood) and the faculties of human nature attached to human personhood.

From the perspective of doing justice to our fellow-men, Luther, in his Large Catechism (LW, (BC, LC (1529)), 1, 223), states some of the implications of the seventh commandment, extending far beyond the mere attachment of a corporeal thing to our persons. The positive duty to do justice to our neighbours demands of us not to harm our neighbour, not to take advantage of him, or to defraud him by any faithless or underhand business transaction - more than that, 
we are under obligation "faithfully to protect his neighbour's property and further his interests" (LW2, [BC, LC (1529)], 1, 223). ${ }^{3}$ In the widest sense, all the properties and faculties of human nature, connaturally acquired, could be included in a person's ownership - also the products of his authorship and mental ingenuity in so far as these are united with the personhood of a human being. 4

Natural (or fundamental) rights in Luther's thought take their origin from man's conscience of freedom and the freedom of conscience flowing therefrom. As such the principles governing human right are stamped on the minds of the human person. The freedom of human personhood provides fundamental right with its form whereas the faculties of human nature attached to human personhood give right to its content. From the remarks above it appears therefore that in a wide sense ownership emerges on the material side of right, and that all fundamental rights are somehow posited by freedom and informed by ownership. Therefore, apart from the ownership flowing from the attachment of corporeal things to human personhood, ownership manifests itself also in the faculties of human nature "naturally attached" to human personhood.

The moral context of fundamental rights is determined by a number of important factors: firstly, that in the deepest seat of human personhood, all men are morally equal; secondly, because of the human being's fall into sin, his natural knowledge of justice and law became infected by sin; thirdly, the effects of sin produced all kinds of inequalities and disparities in wealth, abilities and merit; and fourthly, that moral right arises from man's inclinations towards truth, justice, virtue and well-being.

Within the moral order pertaining to being, jural right can broadly be defined as a modality of personhood, taking its origin from the moral duty preventing harm to the goods of truth, virtue and well-being.

2 In this article $L W$ refers to Luther (1999).

3 In $L W, 18$ [LMP(I)], Micah 6: 9 Luther explains justice as follows: "It means to harm no one, to render to each person what is his own, to bother no one; on the other hand, to help others, to promote their welfare, to prevent damage and violence, so that the wealthy may not surround and oppress the needy, and so that the guilty may be punished and the innocent protected." Also see $L W, 25$ [LR], Romans 13: 6 - the superior principle of justice being to give each his due. freedom of the person attaching the property for his own ends. 
The right to property could, therefore, be described as that modality of personhood or governance taking its aim from the moral obligation to respect the ownership of a human being for promoting the goods of truth, virtue and well-being.

This view of the right to property gives expression to the various relationships attached to the personhood of being and the moral obligation of other persons consonant with the ownership and the rights attached thereto within the moral order of being.

\subsection{Being, ownership and the right to property}

Man's first and foremost consciousness is that of Being because man exists in God's world and the whole of mankind is subject to God's universal providence. God's sovereign will and providence also extends to all that we may possess. Therefore, we may pray that our Father in heaven will deliver us from all manner of evil, whether it affect body and soul, property or reputation ( $L W$, [BC, SC (1529)], 3, 20). When we pray to God for our daily bread, it means everything required to satisfy our bodily needs, such as food and clothing, house and home, fields and flocks, money and property (LW, [BC, SC (1529)], 3, 14).

All people are subject to God's eternal providence because God has created us and all that exist: "he has given me and still sustains my body and soul, all my limbs and senses, my reason and all the faculties of my mind, with food and clothing, house and home, family and property"; He provides us daily and abundantly with all the necessities of life; He protects me from all danger, and preserves us from all evil (LW, [BC, SC (1529)], 2, 2). Commenting on Genesis 31:9, Luther attributes Jacob's delivery from the avarice of Laban to God's intervention, through the Holy Spirit, to set free the captive property held by Laban (LW, 6 [LG], Genesis 31:9). From Luther's comments on God's universal providence, the foremost principle to be reckoned with in the moral order of Being is to honour Being for what it is. Man is not dependent on anything he has or receives, but solely on God (cf. Althaus, 1972:107; WA (S), 15:302 ( $L W, 45: 257-$ 259 [CS(II)]). The presence of Being is universally felt and although human beings deny the existence and providence of God's omnipotent Being. It makes itself felt and "testifies" (as it were) wherever man intuitively experiences a sense of obligation. The universal presence of God "cries out" as it were, for human beings to honour Being for what it is - also in the domain of man's earthly belongings and property: 
Even if you should become rich justly and with God's help, do not depend on this either, and do not make Mammon your god. Property is not given to you for you to build your trust on or boast about all of which is vanity and nothing, but for you to use, enjoy and share with others. But men are not content with this. They make princes and property their boast and build their confidence on them, that is, on nothing, and nothing is what they get from the devil. For gold makes one bold; but it is not really gold, and it does not keep one bold. (LW, 14 [SP(III)], Psalm 62:10.)

When we contrast God and man, we get a glimpse of the almighty immanence of God, we discover that on God rests our salvation and our glory, "(t)hat is, God is both willing and able to help, He gives health, happiness, and salvation. You can depend on this. He is also my 'Glory'; that is, He also provides me with enough possessions, power and prestige, all of which are glorious things" (LW, 14 [SP(III)], Psalms 62:8). Luther adds:

... whatever I can have on earth - health, strength, property, glory, good reputation, power, authority, and everything else - I refuse to commit or entrust it to the emperor, to kings or princes, or to any other man; nor do I expect to get it from any of these. I shall let it stand or fall, come and go, with God. If He holds it up, it will stay, even though the whole world should want to knock it over. If He knocks it over, it will fall over, even though the whole world should want to hold it up. (LW, 14 [SP(III)], Psalms 62:8.)

In sum, Luther teaches that in the moral order Being, being and property should be appreciated for what they are respectively. Therefore, attaching something to my person stands, firstly, in a direct relationship to the providence of the divine Being; secondly, it is directly related to the moral order of the created being. The whole order of created being belongs to the order of creation. It is also subject to the "common order of Christian love" (Raath, 2006:174). Therefore, human life - including the attachment of something to personhood - is universally subject to moral duties. $\mathbf{5}$ Considered within the context of right, fundamental rights can, therefore, be described as duty-based legal entities, enforceable within specific

5 Because love is the fount and origin of man's moral duties. The duties pertaining to man's actions are prescribed and circumscribed by the natural law and the moral law of love respectively: "Quia tenemur tabulae secundae obedire, id est, iure divino est naturali corpus et hanc vitam fovere, alere, tueri, administrare." 
moral limits, stamped on man's conscience to serve God and one's neighbours (Raath, 2006:178).

\subsection{Human nature and the fundamental right to ownership}

The corollary of the duty to honour Being, and appreciate being for what it is, is the obligation to regard property for what it is. In his comments on Genesis 4:3, Luther observes that "(t)he purpose for which God gives us good health, wife, children, and property is not that we might offend Him by means of these gifts, but that we might recognise His mercy and give thanks to Him" (LW, 1 [LG], Genesis $4: 3)$.

Due to the sinful nature of human beings, the good gifts received from God are abused, contrary to the normative order of God's providential government of the world. Luther gives a number of examples to illustrate the evil use of property. One such case in point is the greed of Schechem and Hamor. In his exposition of Genesis 34:23, Luther concludes that they acted fraudulently, or at least, that they deceived their fellow citizens, because it was not in the agreement that all property which the sons of Jacob had would be their common property in the future. Therefore, if they said this seriously, it is a case of manifest fraud and ill will, by which they "not only omit to acknowledge the rape of the girl and the insult previously offered, but they are also thinking of getting the best of Jacob and plundering his goods" (LW, 6 [LG], Genesis 34:23). Therefore, Schechem and Hamor act deceitfully, whether it is in deceiving the sons of Jacob or in telling lies to their fellow citizens ( $L W, 6$ [LG], Genesis 34:23). Their manifest avarice leads further to the rape of a girl, and their sin of avarice draws further sins in its wake, because "(i)f the devil succeeds getting his head into a hole, the snake soon slithers after it with his tail" (LW, 6 [LG], Genesis 34:23).

A second example cited by Luther, is that of the public officials mentioned in Zephaniah 3:3: "Her princes within her are roaring lions; her judges are evening wolves; they gnaw the bones till the marrow." Luther comments to the effect that such is the madness of their officials, "so great their greed," that they are insatiable; "(y)ou see, so great a zeal for acquiring has swept over them that they want to swallow up the entire population and at the same time have all the resources and property of that people" (LW, 18 [LMP(III)], Zephaniah 3:3). 
In a third instance, from his Table talk, Luther declares that where there is property there are all sorts of sins, for property produces effrontery, effrontery produces poverty and poverty produces humility. In addition wealth, talent and beautiful form are fine gifts of God, but people use them badly ( $L W, 54$ [TT], No. 5395, between April 11 and June 14, 1542). However, this does not diminish the fact that a rightful use of property, based on the constituent elements of the natural right to property, can also be discerned.

\section{The constituents of the natural right to property and its legitimate application}

\subsection{The right to property presupposes an upright activity by the owner of property}

To Luther, all human activities are subject to the requirements of the moral law. Man's activities are "guided" by the moral law so to speak. These activities involve doing justice, seeking the truth, promoting virtue and the enjoyment of human well-being. In his comments on Cicero's work in comparison with the contents of the Scriptures, Luther observes that experience demonstrates the efficacy of divine truth - the more it is read, the more it works. With all his wisdom and eloquence Cicero could not achieve this, although he was supreme in human wisdom (LW, 54:171 [TT], collected by Conrad Cordatus, No. 2808b).

In the Table talk Luther stresses the fact that the glory of a good character is to seek the truth and to rejoice in guilelessness ( $L W$, 54:322 [TT], recorded by Anthony Lauterbach, No. 4128). In the world, however, seeking truth is an onerous and burdensome venture: "Truth and right are set forth very well in the books, but in practice they are nothing ... Alas, truth, right and justice are odious things in the world. It is as Pilate replied to Christ, 'What is truth'." ( $L W, 54: 273$ [TT], recorded by Anthony Lauterbach, No. 3793).

Regarding virtue, Luther holds that apart from the common estate of love, binding every person to do "infinite external duties to men", all persons are obligated to do good works. Although no virtue justifies a person before God, all human beings are obliged to perform virtuous deeds of love. In the Book of concord, Luther stresses that we have the Ten Commandments as a summary of divine teaching on what we are to do to make our whole life pleasing to God ( $L W$, [BC, LC (1529)], 1, 313). God's commandments are the true fountain from which all good works must spring, "the true channel 
through which all good works must flow"; "(a)part from the Ten Commandments no deed, no conduct can be good or pleasing to God, no matter how great or precious it may be in the eyes of the world" (LW, [BC, LC (1529)], 1, 313).

All human beings have the same commandments inscribed on their hearts, minds, and conscience, via the duties of the natural law of love. Therefore no human being - whether Christian or pagan - can escape these duties. Luther summarises the duties of virtue as follows:

[Y]ou are to do your neighbour no harm, injury, or violence, nor in any way molest him, either in his person, his wife, his property, his honour or rights, as these things are commanded in that order, even though you have the opportunity and occasion to do so and no man may reprove you. On the contrary, you should do good to all men, help them and promote their interests, however and whenever you can, purely out of love to God and in order to please him, in the confidence that he will abundantly reward you for all you do. (LW, [BC, LC (1529)], 1, 313.)

Concerning man's well-being, Luther stresses throughout that it concerns not only man's earthly existence, but also his spiritual life: "What advantage is there in knowing how beautiful a creature man is if you are unaware of his purpose, namely that he was created to worship God and to live eternally with God? Aristotle says something worthwhile when he declares that the goal of man is happiness, which consists in a virtuous life." (LW, 1 [BC, LG (1529)], Genesis 2:22.)

Because property is a gift from God in the order of creation, the lawful use of property is also based on the norm of love in promoting justice, and seeking the truth, virtue and well-being of mankind (see $W A, 51: 384 \& W A, 39(2): 39)$. The right to private property is closely attached to the fact that every person must have something to use in performing the service which he owes his neighbour. ${ }^{6}$ Every person must give to his neighbour; whoever wishes to give must have, and whoever does not have anything that belongs to him is not able to give anything (Althaus, 1982:105).

In his comments on the Sermon on the mount, Luther distinguishes three ways of using our worldly goods on relationship to our neigh- 
bours: firstly, our concern should be about our heavenly treasure that no one can steal from us; secondly, we should voluntarily give to those who are in need; and thirdly, we should lend to our neighbours without charging interest (WA, 6:365 (LW, 45:273 [CS(II)])).

The basic principle involved is that we have been born and called by God to serve our neighbour ( $L W, 7$ [LG], Genesis 41:45). Our property should be used for the benefit of others; it should be a concern of love, not a concern devoted to our own advantage, militating against faith and love: "(t)he man whose money is dear to him and who is on the lookout for his own advantage will not have much regard for his neighbour or for the office that involves his neighbour" (LW, 21 [SMM], Matthew 6:26). ${ }^{7}$ Where our person, property, reputation, or bodies are involved, there we should render God complete honour and service; these are God's property, given by God to help the neighbour (LW, 12 [SP(I)]], Psalms 45:1). We must deal with temporal goods as if they did not belong to us. We must limit our enjoyment of them to what is necessary for the preservation of the body, with the rest we must help our neighbour (LW, 30 [CE], 1 Peter 1:17). 8

How are the obligations to give towards the neighbour and that of preventing harm to the neighbour by punishing theft to be reconciled? Luther distinguishes the inward spiritual kingdom of God from the outward kingdom of the world: "In this way the two propositions are brought into harmony with one another: at one and the same time you satisfy God's kingdom inwardly and the kingdom of the world outwardly." (LW, 45:96[CS, TA].) Therefore, in a community committed to the justice, truth, virtue and well-being of its residents, we should be willing to suffer evil and injustice, and yet at the same time civil authority should punish evil and injustice. We should not resist evil, and at the same time, it should be resisted by those entrusted with maintaining the peace of civil society: "(i)n the one case, you consider yourself and what is yours, in the other you consider your neighbour and what is his". Luther adds:

In what concerns you and yours, you govern yourself by the gospel and suffer injustice toward yourself according to love and tolerate no injustice toward your neighbour. The gospel

7 Before God outward riches count nothing, only the faith of the heart. (Cf. WA, 32:307 (30-40) (Predigten 1530, Reihenpredigten über Matthäus 5-7).)

$8 \quad$ Also see Luther's remarks (WA, 15:300 ff. (7-12)), concerning the norm of love. 
does not forbid this; in fact, in other places it actually commands it. (LW, 45 [CS(II), TA].) $)^{9}$

Through their example all the saints, from the beginning of the world, wielded the sword to protect the life and property of their neighbour, Abraham, when he rescued Lot, and routed the four kings (related in Gen. 14:8-16), although he was a thoroughly evangelical man; Samuel the holy prophet, slayed King Agag (1 Sam. 15:33); Elijah slew the prophets of Baal (1 Kings 18:40) (LW, 45:96 [CS(II), TA]).

\subsection{The right to property presupposes a lawful activity accompanied by the duty on others to respect the activities by the owner of property}

In Luther's moral and jural thought the moral law of love is the source of duty which obliges a person to leave intact and free some activity proper to another person. Ownership, which involves a person joining something to his person, creates a sphere around a person which, if such a thing is separated from his person, causes suffering forbidden by the moral law. Such intrusion, prohibited by the moral law, amounts to infringement of right where the person whose moral domain of enjoying the goods of truth, virtue and wellbeing are unlawfully intruded. In the widest sense, all injury to right amounts to the unlawful injury to what is attached to personhood (ownership). In the strict sense of injury to the jural right of ownership, injury amounts to damaging or separating something used for seeking the truth, virtue or well-being of the owner.

The co-existing principles of personal freedom (constituting the formal principle of rights) and ownership (which produces the matter of rights) produce very important perspectives from a legal philosophical point of view. Firstly, private ownership must observe certain responsibilities of equity and benevolence towards others if it is to be regarded as just (and moral), and secondly, right is present the instant that the bond between personhood and the object becomes a source of moral obligation forbidding others from doing harm. Thirdly, the concept of ownership becomes a right when a person attaches something to his person for seeking justice, truth,

9 The norm of love also forbids the victims of theft to take the law into their own hands - retaking stolen property and punishment is the concern of civil authorities (WA, 6:3 (9-19 (Schriften, 1519-1520). Also see LW (46:22 [CS(III), AP])) on the Christian's duties not to resort to violence. 
virtue or well-being, and the moral law forbids others from harming the owner in his enjoyment of these goods. Fourthly, right of ownership is dependent on duty, which duty corresponds to a right which exists in some other person, and which right is protected by the moral law, and fifthly, the right of ownership is founded in certain moral relationships with other human beings.

The implications of Luther's fusion of the jural and moral dimensions of ownership in the moral law of love produce important results, deviating from the Thomist approach to the right to private property. In the first instance, ownership is a fact of human nature, consisting in the inclination and power possessed by the human person for uniting to his person whatever he considers as good (i.e. promoting truth, virtue and well-being). Ownership, therefore, is natural - similar to the institution of marriage, because it is needed for the wellbeing of human beings. Not all activities in the use of property attached to a person are, however, protected by natural right. Only those activities flowing from the use of property as are applied for the owner's good and towards which others have the duty not to detach or harm, is protected by the natural right to property, and which should be interpreted widely. In his exposition of the duties involved in the seventh commandment, Luther holds that "steal" includes every kind of advantage and this commandment applies in every trade and profession - "(i)t is stealing whenever I get my neighbour's goods into my possession by any means whatsoever" $(L W, 51: 158[S(I)])$.

In the second place, where either the "good" use of ownership or the moral duty of others not to do the owner harm is not present, the owner does not have "a right of ownership" in using his evilly. If property is not appreciated for what it is, for performing upright actions, it is often used by God for punishing those who are kept from obedience to God (see LW, 20 [LMP(III)], Zechariah 1:2). The primary duty of a person is to provide for his body, and to use his property for the good of the neighbour.10 If property becomes a stumbling block for conveying love, such property should rather be forsaken for the higher goal of love (LW, 23 [SJ(II)], John 7:2).

Thirdly, Luther rejects the idea of "communism" expressed by the Anabaptists (Enthusiasts) and the peasants (see LW, [BC, CF], XVI (Civil Affairs, 2, XVI, 2)). Persons may, therefore, engage in the civil 
institutions, being God's "good creatures and divine ordinances" ( $L W,[\mathrm{BC}]$, Article XVI (Political Order)). To Luther it is also false to claim that perfection consists in not holding property. What makes for Christian perfection is not contempt of civil ordinances but attitudes of the heart; "( $\mathrm{t}$ )hough they were wealthy and held high positions, Abraham, David, and Daniel were no less perfect than any hermit" ( $L W,[\mathrm{BC}]$, Article XVI (Political Order)). For this same reason, putting a hypocritical poverty and humility far above the state and the family, and because the Platonic commune does not have God's command, the rejection of the natural right to property is to Luther an evil idea (LW, [BC], Article XVI (Political Order); also see $L W,[B C, F C], 2, X I I I, 2211)$.

The right to hold property is a civil ordinance. It is legitimate to use civil ordinances just as it is legitimate for them to "use the air, light, food and drink" (LW, [BC, AAC (1531)], 1, IV, 50 (Articles VII \& VIII)). The fact that the poor had made their goods common property according to Acts 4:32, is not necessarily normative for all conditions and applicable to all societies (cf. LW, 27 [LGS(II)], Galatians 2:11). 12 This, by implication, does not prevent a community of the poor from making their possessions common property. What does matter primarily, is the demands of love contained in the natural law, the written law and the law of the Gospel (LW, 27 [LGS(II)], Galatians 5:15). The command: "You shall love your neighbour as yourself," says exactly what the natural law says, namely,

[w] hatever you wish that men would do to you [this, of course, is to love oneself], do so to them [as is clear, this certainly means to love others as oneself]. Therefore, there is one law which runs through all ages, is known to all men, is written in the hearts of all people, and leaves no one from beginning to end

11 "The erroneous Articles of the Anabaptists teach that no Christian can with a good conscience hold or possess private property but is obliged to give his property to the community."

12 Also compare Calvin's remarks to the same effect, (Calvin, 1834, CO, 47:96 (Commentarius Ionus et Congretion divinite lesus Christ). For Luther's observations cf. WA (39, (2):63 (1-10); Disputationen 1539/1545)). At 68 (7-12), Luther states: "Communio societatis apostolorum fuit charitatis. Nec ego nego, cum liberum sit proprium retinere vel propter charitatem conferre communem rem ad alendos vicinos. Exempli gratia. Si opus haberet proximus mea opera vel moriens ante faciem meam, tunc mea res non est mea, sondern soll yhm helffen. Charitas est, cum volunt duo aut plures cives sua bona conferre inter se. Quis hoc prohibebit? Si res non facis iure propriae, quomodo posses eas facere communes?" 
with an excuse, although for the Jews ceremonies were added and the other nations had their own laws, which were not binding upon the whole world, but only this one, which the Holy Spirit dictates unceasingly in the hearts of all. (LW, 27 [LGS(II)], Galatians 5:15.) 13

In the fourth place, the right to private property and ownership should not be confused with the duty to assist and serve the poor. In the case of need, love (not just jural right) removes the boundary line between mine and yours; when my neighbour is in need my property is no longer mine (in a moral sense) but is set aside for the service of the neighbour. 14 The sharing of the possessions among the early Christians was such a work of love. Therefore we cannot make such a voluntary act a general principle (WA, 39(2):63, 68-69; $W A, 18: 359$ ( $L W, 46: 51)$ ). Civil officials (and all members of civil society) must have money and property available to serve the poor (WA, 32:307 (4-18) (Predigten 1530, Reihenpredigten über Matthäus 5-7); 15 (LW, 21:12 [SMM])). We are not dependent on anything that we receive but solely on God, because when we lend to others and lose our property, God will pay us back (WA, 15:302 $(L W, 45: 257-259))$. Luther's statements in this regard not only support the idea of generous support of the needy by the community

13 The seventh commandment permits one to have one's own money and property and only forbids one unlawfully taking property of another (LW, 34:42 [CR(IV), EGA]).

14 Cf. WA (6:36 (27-31); Schriften 1519-1520): "Gleych wie Christus fur dem Bischoff Annas, da er den Backenschlag empfieng, hylt er den ander, auch den selben, widder dar, und bereyd war, mehr zu leyden der selben schlege, Ja in seynem gantzen leyden sehen wir das er nie keyn boesse wort odder that betzalet odder widder holet, sondern altzeyt bereyt ist, mehr und mehr zy leyden." Also note WA (32:395 (23-29); Predigten, 1530: Reihenpredigten über Matthäus 5-7, 1530-1532).

15 At (19-29) Luther remarks as follows: "Zum weltlichen regiment gehoret, das man gelt, gut, ehre gewalt, land und leute habe und kan on das nicht bestehen. Darumb soll und kan ein herr odder fuesrt nicht arm sein. Denn er mus allerley solche guter zu seinem ampt und stand haben. Darumb ist nicht die meinung, das man so muesse arm sein, das man gar nicht eigens habe, Denn es kan die wellt nicht so bestehen, das wir alle solten bettler sein und nichts haben. Denn auch kein hausvater sein haus und gesind neeren kuende, wenn er selbs gar nichts hette. Summa: leiblich arm sein thuts nicht, denn man findet manchen bettler, der das brod fur der thur nimt, so stoltz und boese als kein reicher, und manchen schebichten bawrn, mit dem weiniger umb zo komen ist denn mit keinem herrn und fursten." 
but make it a moral duty to be performed in love, in order to further benevolent fellowship in civil society ( $L W, 35: 52$ [W\&S(I), BSBC]). ${ }^{16}$

Fifthly, the moral duty of support to the poor through our possessions extends to all the property we may have in excess of preserving our life and those of our families. The three important considerations advanced by Luther are the following:

- We may not bind ourselves inseparably to our personal property because we are to remain free for the sake of the gospel (WA, 39(2):40).

- Personal possessions and property cease to be "goods" when they are piled up in a spirit of avarice and selfishness (WA, 19:561 (4-7) (Schriften, 1526) 17; (LW, 14:219 [SP(III)])).

- Property in excess of what we need to preserve ourselves and our families is "unrighteous Mammon". Thus, says Luther, Mammon may also be used for evil purposes, and Jesus then calls it "unrighteous Mammon". In God's sight everything which a man has left over and does not help his neighbour with, is an "illegal and stolen possession (in a moral sense); for before God one ought to give, to lend, and to let everything be taken away from him". 18 Therefore the popular proverb says that "the big shots

16 Benevolent fellowship in civil society entails that

(a)Il sufferings and sins ... become common property; and thus love engenders love in return and [mutual love] unites. To carry out our homely figure, it is like a city where every citizen shares with all the others the city's name, honour, freedom, trade, customs, usages, help, support, protection, and the like, while at the same time he shares all the dangers of fire and flood, enemies and death, losses, taxes, and the like. For he who would share in the profits must also share in the costs, and ever recompense love with love. Here we see that whoever injures one citizen injures an entire city and all its citizens; whoever benefits one [citizen] deserves favour and thanks from all the others.

17 Also note the following remarks by Luther (WA, 36:562 (1-4) (Predigten 1532): "das ist aber ein troestlicher undetscheyd der gueter, das der gottlosen guter nicht allein vergenglich sind und ein ende haben, sondern auch boese gieter sind und verdamlich, daruemb das sie nur auff hauffen gesamelt und nicht der durfftigen mit geteylt werden, wilches widder die natur der gueter ist".

18 At WA (6:47 (4-13); Schriften 1519-1520), Luther remarks as follows: "Czum achtzehenden. Nu kommen wir zu dem dritten grad, die zeytlichen güter zu handeln. Der ist, das wir willig und gerne leyhen oder borgen sollen, an allen auffsatz und zinns: davon sagt unser herr Ihesus Christus Matt. V. Und wer von dir entleyhen odder borgen will, von dem kere dich nit, das ist, vorsags yhm nicht. Dysser grad ist der aller geringste und ist auch ym alten Testament 
are the biggest thieves, for they have the most left over and give the least" (WA, 10(3):275 (7-12) (Predigten 1522)).

\section{Jural limits to ownership and the right to private property}

\subsection{Limitations to moral freedom}

The duty on $A$ to act morally free (justly) does not depend on the moral duty of $B, C, D$, and $E$, not to harm him. A's duty flows from the demands of justice to render to each his due, including that which is morally (and not only legally) due. A's acting morally free does not entail that others have the duty always to respect his freedom, because there are also limits to acting morally free (that is, acting justly). The fact that an owner's (for example A's) activity promotes the good, in other words, is "morally free", by striving towards promoting justice, truth, virtue and well-being, does not mean that $A$ has an immoderate freedom in performing upright actions, merely because others ( $B, C, D$, and $E$ ) are obligated to respect the actions of $A$. The jural right flowing from performing upright activities by $A$, towards which $B, C, D$, and $E$ have the duty of respect, is limited by their freedom in performing actions and enjoying the freedom of their own endeavours in performing upright activities, and towards whom others (for example $A$ ) have similar obligations. Furthermore, the duty of $B, C, D$, and $E$ towards A's life, wife and property does not entitle $A$ to do moral evil, because he is bound by the tenets of acting morally upright (justly).

\subsection{Limitations to the moral duties of others to respect the activities of owners of property}

The duty on others, for example B, C, D, and E, not to do harm to A and what is his does not depend on the moral freedom of $A$ to act justly, because if A performed morally unfree acts, for example refusing to act benevolently towards members of civil society, B, C, $D$, and $E$ are not exempted from the duty to respect A's life, wife, possessions and so forth.

gepotten, do gatt sagt Deutro: XV. So yemand auss deynen bruedernn yn deyner statt arm wirt, soltu deyn hertz nit kegen yhm vorharten, noch deyn hand zu halten, ssondern solt sie auff thun und uhm leyhen alles wess er bedarff. Und dissen grad haben sie lassen bleyben eyn gepott. Dan alle lerer hie zu sammen stymmen, das leyhen odder borgen soll geschehen frey ..." 
The mere fact that the activities of $A$ are not directed at the moral good of acting uprightly, does not provide B, C, D, and E with the right to claim such property for distribution among the poor. Quite often the claims of those persons (B, C, D, and E) who promote the idea of equalising property in civil society, amount to despoiling the rich $(A)$ who, in their view, do not contribute sufficiently to assisting the poor. The limits to the claims of the equalitarians $(B, C, D$, and $E)$ to despoil the avaricious rich $(A)$ of his property are contained in the fact that, although the rich $(A)$ has no "right" to abuse his riches by furthering evil, he nevertheless has a right to his wealth and the right not to be deprived of it. So, for example, the fact that a rich person, A, promotes prostitution or the spreading of HIV and AIDS, does not provide him with the moral freedom to undertake these activities, and does not, thereby, absolve B, C, D, and E from the obligation to respect A's evil use of his property; it does not remove the fact that $A$ has a right to his wealth and a right not to be deprived of it.

\subsection{The limitations on civil authority to interfere with the avariciously rich person's right to his wealth and the right not to be deprived of it}

\subsubsection{All actions by civil authorities must be aimed at promoting peace, order and the common good}

The basic principle advanced by Luther is that civil laws are necessary for administering matters of ownership and property. The main duty of civil authority is to prevent theft, robbery and stealing. ${ }^{19}$ If civil authorities neglect these evils peace, business and commerce will be destroyed. 20 Christian love does not replace the law which civil authorities are responsible for administering (WA, 15:302 (LW, 45:258)). If civil laws and the civil institutions for maintaining and enforcing the law were weakened, and only love applied, everyone would eat, drink, and live at ease at someone else's expense, and no one would work; everyone would take from another what was his, "and we would have such a state of affairs that no one could live because of others" (WA, 15:306 (LW, 45:264)). 21 Peace is the guid-

19 Note Luther's statements regarding the duties of civil authorities to strictly enforce the civil laws (WA, 15:302 (13-29); Predigten und Schriften 1524).

20 See the following: (WA 15:302 (LW, 45:258); WA, 15:306 (28-36) (Predigten und Schriften, 1524) (LW, 45:264)).

21 Also note WA (10(3):277 (1-8) (Predigten 1522)). 
ing principle in all affairs and activities of civil authorities: "We must not pray to live in wealth but to ask that godliness and dignity may be able to exist through peace. The ungodly use peace for shameful wickedness. We use peace that we may more quietly be able to discuss the Word, extend the faith, and bring up our children in spiritual corporeal and moral discipline - in Christian discipline"; these are the examples of an upright life ( $L W, 28$ [C\&T], 1 Timothy 2:2). Maintaining peace in civil society also carries with it the duty on civil authorities to protect the poor from being exploited by the rich (see $L W, 47: 273$ [CS(IV), OJ]).

\subsubsection{All actions by civil authorities must be performed lawfully}

Luther had a great concern for justice and equity in the economic sphere and assigned the responsibility for the attainment of this end to those in authority. Whilst affirming the validity and worth of private property on the one hand, he exposed the self-seeking avarice of those in office on the other. On the positive side, the king has a sword to protect the innocent and to punish the guilty. God does not permit any evil-doing in the land which he does not punish through the magistrates. 22 If the lower magistrates do not do it, the superior will; that is, it eventually comes under the power of the sword. The king is also called "the cultivator of the earth", which does not refer only to the practice of agriculture but to the conservation of the entire commonwealth, as this goes on through laws, judgments, and so forth. It is the king's duty to protect and to nourish and enhance the goods and the property of the people ( $L W, 15$ [ESL\&S], Ecclesiastes 5:10). The king's duty is to strengthen us against offences (LW, 15 [ESL\&S], Ecclesiastes 5:10). 23

Later reformers organised the legal obligations of the civil authorities in the sphere of dealing with private property as developed by Luther into a much more systematic corpus of principles. The Geneva reformer, John Calvin, contributed substantially in postulating the jural limits pertaining to civil government's administration of private property in the civil sphere. Firstly, Calvin supports the views of the Glossators in stating that the role of civil authorities is largely limited to the protective functions of guardianship towards private property

22 Therefore, there is a clear distinction between jural laws for administering justice, and the reign of Christ in the moral sphere (WA, 51:377 (5-13) (Predigten 1545-1546: Auslegung des 23. und 101. Psalms 1534-1536 \& c.)). 
(Calvin, 1834, CO, 29:554 [SD5\&HS]). Only where the common interest demands it, do the civil authorities have the power to limit private rights, provided this is done on reasonable grounds. The right to private property is a natural right. Therefore, rulers are prohibited from unlawfully interfering with the property rights of their subjects - a view in agreement with Calvin's approach in his Institutio (1536) (see Calvin, 1834, CO, 1:230 [I]). This approach was developed in his Commentary on Samuel, where civil authorities are bound to the principles of distributive justice (ut suum cuique salvum sit et incolumne). This demands not merely the protection of private property against interference by private persons, but it also demands from rulers the careful application of the right to expropriation - only in cases of "urgent need" are extraordinary measures of obtaining private property allowed. However, urgent need does not include the tyrannical rapaciousness of rulers to confiscate property at will (Calvin, 1834, CO, 40:713 [PE\&PD1]). In such instances the private owners should be adequately compensated for the loss of their property because the rights of both civil authorities and individual persons flow from and are protected by the universal precepts of natural law (cf. Calvin, 1834, CO, 29:558 [SD5\&HS]).

\subsubsection{All actions by civil authorities must be performed wisely and bona fide}

Luther's thoughts on the duties and rights of civil authorities in despoiling the avaricious rich to the benefit of the poor through levies and taxes, cover a vast field, therefore only the essential aspects of his views will receive attention albeit briefly and superficially. Apart from acting lawfully, civil authorities are admonished to perform their functions and duties with the necessary wisdom. Even though Luther, on theological and moral grounds, is not in favour of interest, he declares that it would not be wise to simply abolish interest but pleads for it to be "shaped rightly" (WA (Br), 3:485-486 (16-60) (Briefe 1523-1525): Luther - Rat zu Danzig). 24 Firstly, the freedom

24 "Hier soll man nicht zufahren und alle Zwiepaltung stracks abtun nach dem Evangelio. Es hat es auch niemand Recht noch Macht, denn sie ist aus menschlicher Ordnung hergekommen, welche St. Petrus nicht will zerissen haben, sondern man solle es predigen und denen hingeben die Zinsen, denen sie gebühren, ob sie von innen selbst soch Evangelium wollen annehmen und den Zins fahren lassen onder nicht. Nicht weiter kann man sie dringen. Denn das Evangelium erfordert willige Hertzen, die der Geist Gottes treibet. Aber das soll man tun mit den Zinsen, dass man menschliche Ordnung, Gesetze und Gebräuche in solchen Zinsen, so sie zu weit greifen, zurechtebringe und nach der Billigkeit, das man heisst ... oder aequitas, richte. Denn alle Gesetze und 
of civil authorities to exact taxes belongs to the realm of creation: under the divine law subjects have the duty to pay taxes, because civil authorities "are ministers of God" (LW, [BC, SC (1529)], VIII). ${ }^{25}$ The payment of taxes by subjects is a public duty, not a private affair (LW, [BC, AACF (1531)], 1, XII, 81). 26 This entails that civil rulers are allowed to request the payment of taxes, revenues "and other payments of this kind" ( $L W, 1$ [LG], Genesis 3:19) because such payments pertain to the order of creation and are not needed for attaining one's salvation ( $L W, 4$ [LG], Genesis 23:4). 27 Secondly, the demands of taxing the subjects should not over-burden the populace or amount to "plundering": Luther explicitly condemns the practices of the avaricious rulers who over-tax their subjects, because tariffs and levies are increased exceedingly. Whereas earlier regulations ordered the payment of one out of twenty guldens, nowadays two or three are demanded, "and new frauds and taxes are being devised every day" (LW, 7 [LG], Genesis 41:36). 28 Thirdly, civil rulers, in their gathering and spending of

Gwohnheiten sollen der natürlichen Billichkeit als ihrer Regel und Meisterin unterworfen sein ... Denn das Evangelium lehret wohl frei alle Güter lassen fahren, aber wer mich dazu dringet oder zwinget, der nimmt mir das Meine ... Kurzumb: hierin auf diese Weise zu handeln, kann man kein Gesetze furschreiben, sondern es stehet alles in Ansehen der Person, welche man nach der Liebe und Billigkeit, durch Erkenntnis guter Leute, muss tragen und nicht verderben lassen, sonsten würde eitel ...".

25 Luther warns against expecting too much from civil authorities: "You must know that since the beginning of the world a wise prince is a mighty rare bird, and an upright prince even rarer. They are generally the biggest fools or the worst scoundrels on earth; therefore, one must constantly expect the worst from them and look for little good ..." (LW, 45:109 [CS(II), TA]).

Also see $L W(45: 94$ [CS(II), TA]).

27 This implies inter alia that the spiritual and earthly realms should not be confused or mingled, one of the implications of which being that civil authorities should not govern their subjects with arrogance or in an overbearing manner and attitude, thereby arrogating to themselves a Messianic status, or always "wanting to have pre-eminence because they think their honour, persons, affairs, their rights, their power must be over all possession, honour, persons, affairs and dominions" (LW, 52:215 [S(II)]).

28 For Luther's complaints about excessive taxation see the following: ( $L W 8$ [LG], Genesis 45:18; LW 8 [LG], Genesis 47:25). Excessive taxation is used by God as punishment for man's sins: $L W, 8[\mathrm{MP}(\mathrm{I})]$, Hosea 8:10: "First let them [civil rulers] suck you dry by taxation, wear you out and tax you to death; then I [God] will take them away ..."; $L W 18$ [MP(I)], Amos 6:6: "They do not listen to their own subjects, in fact, they oppress them with unbearable taxes and then drain off whatever they still have!" Luther gives the following illustrations of the excessive levels of taxation exacted by the German princes and the usurers: up 
taxes, may sometimes act just as avariciously as the rich from whose hands the funds for the needy must be wrenched ( $L W, 6$ [LG], Genesis 3:16). Fourthly, care should be taken not to overburden those who are already in need, because alleviating the needs of the poor should have priority ( $L W, 9$ [LD], Deuteronomy 15:19). ${ }^{29}$ Fifthly, rulers should seek the will of the Lord and the interests of their subjects, and not their own interests; nor should the judiciary support the evil avarice because judges are inclined to serve the interests of the rich (see $L W, 18$ [LMP(I)], Micah 7:3). Sixthly, it entails that civil rulers should not burden their subjects for purposes of satisfying their own vanity, for example erecting lavish

to his own time, says Luther, taxes have been moderate, since one out of twenty guldens was paid, according to the laws which demand five out of hundred - in other words a twentieth, so to speak. The Jews had tithing: out of twenty they gave two, both in the produce of the fields and in all their property. Up to Luther's time, the German nation had been more fortunate than the Jews were. Later on Egypt was oppressed more than the Jews, although it was tolerable enough if Egypt had no other tax to bear than that quint. In Luther's day, with increasing usury, taxes, and greed, the Germans were paying not only a fifth but a quarter and nearly a half. The usurers of Leipzig and the nobles added to the avarous "plundering" of the people, because they received twenty out of 100 guldens, which is a fifth part. Although the government in Luther's time did not yet demand as much as this, the private usurers extorted a fifth part by means of usury. To this taxes and regular revenues were later added. Therefore those who previously paid a twentieth were now paying a third and a half, and, says Luther, were "being absolutely robbed". Taken together, the nobles, the merchants, and those "addicted to tyrannical practices are bringing it about that we keep barely a heller" (LW, 7 [LG], Genesis 41:36). To obtain a fuller picture of Luther's criticism of the high levels of taxation, it helps to bear in mind that in Spain, for example, the sales tax was ten percent of an article each time it was sold. Also note $L W$ (8 [LG], Genesis 42:14). Although Luther is not in favour of introducing the Mosaic civil and political laws, he observes in tithing a just system of taxation (cf. LW 9 [LD], Deuteronomy 15:1: "But let us return to Moses. Behold his excellent order of procedure! ...). Then he deals with the triennial tithes, by which any poor are to be helped" (also see LW, 35:166 [W\&S(I)] and LW, 35:166 [W\&S(I)]; also compare LW, 18 [LMP(I)], Micah 6:9; LW, 19 [LMP(II)], Habakkuk 2:19; LW, 39:19 [C\&M(I), SOB]; LW, 44:211 [CS(I), CNGN]: "... let him free our lands from his intolerable taxing and fleecing, let him give us back our liberty, our rights, our honour, our body, and soul; and let the empire be what the empire should be"; $L W, 45: 109$ [CS(II), TA]; $L W, 48: 51$ [L(I)] (WA (Br), 1, No. 51); LW, 48:49 [L(I)]; LW, 48:142 [L(I)]; (WA (Br), 1:604; $L W$, 49:28 [L(II)])).

29 See: (LW, 18 [LMP(I)], Amos 5:11: "You burden, you oppress the poor, and impose burdens on them. They are not up to bearing those burdens. You husk the wretched masses, you demand intolerable taxes. You erode their goods legally and illegally."; also see $L W, 18$ [LMP(I)], Micah 7:3; LW, 52:228 [S(II)]; $L W, 54: 345$ [TT, Recorded by Anthony Lauterbach].). 
buildings and so forth (LW, 19 [LMP(II)], Habakkuk 2:19). 30 Seventhly, subjects should support their rulers and render to them what is due by way of $\operatorname{tax}(L W, 21$ [SMM], Matthew 7:13). 31

\section{Conclusions}

- The medieval approach to the issue of natural rights to property and ownership produced three distinct lines of thought. The first, represented by St. Ambrose (and others) held that originally no natural right to private property existed, that nature provided a common right to property, and as a result of man's fall into sin, usurpation led to private property.

The second view, held by Thomas Aquinas, advanced that although private property is lawful and not contrary to nature, private property cannot override the common right of mankind to the necessaries of life. Thus almsgiving belongs to love, although it is also a matter of obligation; i.e. although temporal possessions are private as regards ownership, as regards use they belong to others who have a need for them, and in cases of extreme necessity all things are common property.

The collapse of the Medieval order, the rise of the nation state and the upcoming absolutism of civil rulers, necessitated the early reformers to make a clearer demarcation between the natural right to private property and the moral conditions giving rise to such a right, and a clearer delineation of the duties of civil authorities in dealing with private property in civil society.

Luther's view that natural right presupposes the existence of moral duty and is intricately connected with the moral uprightness of the owner's activities, produces a number of important perspectives. It enables one to state the moral conditions for the existence of natural right more clearly; all rights to acquired property presuppose the duty to respect the legal governance of the owner, based on the moral law; divine law

See e.g. $L W(22[S J(I)]$, John 1:14).

31 "The people are also to be exhorted to pay honestly and willingly the tax imposed on each. Even if some obligations are heavy each one is bound to pay on account of his duty and his obedience to government so that peace may rule throughout the land. For what else is unwillingness to pay tax or render service than giving rise to thievery and murder?" ( $L W, 40: 286$ [C\&M(II), IPP]). See also LW, (40:286 [C\&M(II), IPP]). 
subjects people to the moral duty of support of the poor and those in need; the duty-based roots of the right of ownership and private property, limit the unjustified claims of the avaricious rich to enjoy unlimited freedom, and the demands of those, in the absence of morally upright activities on the part of the owner, to negate his right to private property and to demand the redistribution of the owner's goods; owners subjected to the forceful removal of the enjoyment of their property, do not have the moral right to take the law into their own hands and retake their property; a basis is provided for the state to limit the right to ownership in the case of extreme necessity, through reasonable expropriation, taxation and imposing of levies.

Luther's basic message is that those who have enough and do not provide for those in need and are not touched by the conditions of the destitute, are serving Mammon and not Christ. This, however, does not provide civil authorities with a "right" to confiscate and/or redistribute property at will.

- The Lutheran views on the natural right to private property have important legal philosophical consequences for the discourse between reformational, capitalist and communist views on the rights to ownership. The Lutheran-reformist view based on the common moral duties of mankind irrespective of the existence of civil laws dealing with these matters, opposes the theories of those who deny the existence of such a right. They attribute the establishment of individual ownership to civil laws, to the effect that - as stated for example by Thomas Hobbes - in the state of nature everybody has a right to everything and consequently no individual person can peacefully retain anything. The notion of the natural right to private property rejects the idea that rights to property originate from the protection of privately owned property by a civilly constituted society providing coercion to make it enforceable - as Jeremy Bentham teaches - because a right is a moral, not a physical, power provided by human society. The moral duty from which the right to private property arises is closely attached to human personhood. Therefore, views on rights that exclude reason and morality from right as such - as J$\mathrm{J}$. Rousseau avers - and degrade natural right to the level of animalistic and not human right, are untenable, because in such a philosophy of right, right as such is annihilated. The true concept of property right presupposes moral relations between individuals, not simply a concept of right postulated as "qualities" inherent to the nature of the individual - similar to John Locke's 
teachings - because such a notion of right effectively destroys natural right and only selfish right remains. Ownership rests on both the physical bond of attachment of a thing to personhood and the moral bond of preventing injury to property and therefore, the view that occupancy extends to everything an individual is capable of defending - for example Immanuel Kant's view derives ownership from force rather than the moral law, and therefore lacks the moral basis for establishing right. Because the natural right to property presupposes the moral duty to prevent harm to others, the idea of the natural right to property is irreconcilable with the radical views which are committed to principles advancing that each individual has a right to an equal portion of external ownership, or which holds that there is a right to give to each according to his need or that ownership belongs to no one in particular but to humanity as a whole, although the use of a thing belongs to individuals. Such views negate the physical-moral bond existing between a thing and a person, and establish fictitious rights on the basis of need in opposition to the statement of natural individual rights contained in the seventh commandment.

- Those philosophies denying the natural right to private property fail to explain the origin of a right on the part of civil authority to deal with private property in an arbitrary fashion and irrespective of the moral basis for the existence of individual ownership. If ownership did not exist and could not exist before the existence of civil society, how could the founders of civil society (or a new constitutional dispensation) make laws to something they had no right to? By implication this means that the justice of ownership depends on ownership itself and not on the fictitious consent of those who judge it useful for themselves and for their own utility. The justice of ownership flows from the principle of not doing harm to anyone, because we harm others everytime we damage or remove that which is joined to them personally. This joining of something to human personhood becomes a right immediately when the duty of not doing harm is morally established.

- Does the right to private property exclude state interference in the domain of private ownership in order to support the destitute, the poor and those in need? The answer is categorically negative. The first principle involved is that the avaricious rich who spend their riches on furthering the aims of moral evil should contribute towards supporting the poor and alleviating the needs of the destitute. Intervention through civil authorities (e.g. expropriation) should be performed lawfully and wisely. Civil authori- 
ties have the explicit duty to protect the individual's right to private property from infringement by others. All those who have enough for themselves and their families, have the moral duty (albeit not legal) to support those in need. Civil authorities have the responsibility to protect individuals and their property from violence and the demands of the masses for inconsiderate redistribution of property. Civil authorities should also refrain from acting unlawfully by creating the fictitious category of natural public ownership and despoiling individuals of their natural right to private property.

\section{List of references}

ALTHAUS, P. 1972. The ethics of Martin Luther. Transl. by Robert C. Schultz. Philadelphia: Fortress.

AMBROSE. 1997. [DO] De Officiis (On the duties of the clergy). (In Schaff, P., ed. Master Christian library: the Nicene and Post-Nicene Fathers. Series 2. Transl. by H. de Romestin \& H.T.F. Duckworth. Albany: Books for the Ages.)

AQUINAS, T. 1997. Summa theologica. (In Schaff, P., ed. Master Christian library: the Nicene and Post-Nicene Fathers. Series 1. Transl. by M. Dods. Albany: Books for the Ages.)

ARISTOTLE. 1979. The Politics. Transl. by T.A. Sinclair. Harmondsworth: Penguin Books.

CALVIN, J. 1834. [CO] Corpus Reformatorum. Series 2: Ionnnis Calvini, Opera Quae Supersunt Omnia, vols. 29-87. Halle: Schwetschke. ([CO] 1: [1] Institutio, 1536-1554; [CO] 29: [SD5] Sermons Deuteronome, pars. 5, cap. 32 ad 34; [HS] Homiliae 1 Sam., cap. 1 ad 12; [CO] 40: [PE] Praelectiones Ezechielis, cap. 1 ad 20; [PD1] Praelectiones Danielem, cap. 1 ad 5.)

CARLYLE, A.J. 1913. The theory of property in medieval theory: property: its duties and rights historically, philosophically and religiously regarded. London: Macmillan.

CHRYSOSTOM. 1997. [HM] Homilies on Matthew. (In Schaff, P. Master Christian library: the Nicene and Post-Nicene Fathers. Series 1, vol. 10. Albany: Books for the ages.)

CICERO, M. 1948. [DR] De re publica \& [DL] De legibus. Transl. by C.W. Keyes. London: Heinemann.

CLEMENT OF ALEXANDRIA. 1997. [S]. Stromata. (In Schaff, P., ed. Master Christian library: the Ante-Nicene Fathers. Vol. 2. Transl. by A. Roberts \& J. Donaldson. Albany: Books for the ages.)

LACTANTIUS. 1997. [DI] Divine institues. (In Schaff, P., ed. Master Christian library: The Ante-Nicene Fathers. Series 1, vol. 7. Transl. by A. Roberts \& J. Donaldson. Albany: Books for the ages.)

LUNDEEN, J.W. 1999 (c1986). Luther's works. Vol. 55: Index. Ed. by J.J. Pelikan, H.C. Oswald \& H.T. Lehmann. Saint Louis: Concordia.

LUTHER, M. 1999 (c1955). [SP (I)]: Luther's Works. Vol. 12: Selected Psalms 1 (1532). Ed. by J.J. Pelikan, H.C. Oswald \& H.T. Lehmann. Saint Louis: Concordia. 
LUTHER, M. 1999 (c1956). [SMM]: Luther's Works. Vol. 21: The sermon on the mount and the magnificat. Ed. by J.J. Pelikan, H.C. Oswald \& H.T. Lehmann. Saint Louis: Concordia.

LUTHER, M. 1999 (c1957). [SJ (I)]: Luther's Works. Vol. 22: Sermons on the gospel of St. John: chapters 1-4 (1514). Ed. by J.J. Pelikan, H.C. Oswald \& H.T. Lehmann. Saint Louis: Concordia.

LUTHER, M. 1999 (c1958). [LG]: Luther's Works. Vol. 1: Lectures on Genesis: chapters 1-5. Ed. by J.J. Pelikan, H.C. Oswald \& H.T. Lehmann. Saint Louis: Concordia.

LUTHER, M. 1999 (1958). [SP (III)]: Luther's Works. Vol. 14: Selected Psalms 3. Ed. by J.J. Pelikan, H.C. Oswald \& H.T. Lehmann. Saint Louis: Concordia.

LUTHER, M. 1999 (c1959). [S(I)]: Luther's Works. Vol. 51: Sermons 1. Ed. by J.J. Pelikan, H.C. Oswald \& H.T. Lehmann. Saint Louis: Fortress.

LUTHER, M. 1999 (c1959). [SJ (II)]: Luther's Works. Vol. 23: Sermons on the gospel of St. John: chapters 6-8. Saint Louis: Concordia.

LUTHER, M. 1999 (c1960). [CR(IV)]: Luther's Works. Vol. 34: Career of the reformer 4. Ed. by J.J. Pelikan, H.C. Oswald \& H.T. Lehmann. Saint Louis: Fortress. ([EGA] Exhortation to all clergy assembled at Augsburg (1530), 3-61.)

LUTHER, M. 1999 (c1960). [LD]: Luther's Works. Vol. 9: Lectures on Deuteronomy. Ed. by J.J. Pelikan, H.C. Oswald \& H.T. Lehmann. Saint Louis: Concordia.

LUTHER, M. 1999 (c1960). [W\&S(I)]: Luther's Works. Vol. 35: Word and sacrament 1. Ed. by J.J. Pelikan, H.C. Oswald \& H.T. Lehmann. Saint Louis: Fortress. ([BSBC] The blessed sacrament of the holy and true body of Christ, and the brotherhoods (1519); [CRM] How Christians should regard Moses (1525), 153-174.)

LUTHER, M. 1999 (c1962). [CS(II)]: Luther's Works. Vol. 45: The Christian in society 2. Ed. by J.J. Pelikan, H.C. Oswald \& H.T. Lehmann. Saint Louis: Fortress. ([TA] Temporal authority: to what extent it should be obeyed (1523), 74-131; [T\&U] Trade and usury (1524), 231-311.)

LUTHER, M. 1999 (c1963). [L(I)]: Luther's Works. Vol. 48: Letters 1. Ed. by J.J. Pelikan, H.C. Oswald \& H.T. Lehmann. Saint Louis: Fortress.

LUTHER, M. 1999 (c1964). [LG]: Luther's Works. Vol. 4: Lectures on Genesis: chapters 21-25 (1539). Ed. by J.J. Pelikan, H.C. Oswald \& H.T. Lehmann. Saint Louis: Concordia.

LUTHER, M. 1999 (c1964). [LGS (II)]: Luther's Works. Vol. 27: Lectures on Galatians, chapters 5-6 (1535); Chapters 1-6. Ed. by J.J. Pelikan, H.C. Oswald \& H.T. Lehmann. Saint Louis: Concordia.

LUTHER, M. 1999 (c1965). [LG]: Luther's Works. Vol. 7: Lectures on Genesis: chapters 38-44 (c. 1543). Ed. by J.J. Pelikan, H.C. Oswald \& H.T. Lehmann. Saint Louis: Concordia.

LUTHER, M. 1999 (c1966). [CS(I)]: Luther's Works. Vol. 44: The Christian in society 1. Ed. by J.J. Pelikan, H.C. Oswald \& H.T. Lehmann. Saint Louis: Fortress. ([CNGN] To the Christian nobility of the German nation concerning the reform of the Christian estate (1520), 114-219.)

LUTHER, M. 1999 (c1966). [LG]: Luther's Works. Vol. 8: Lectures on Genesis: chapters 45-50 (1545). Ed. by J.J. Pelikan, H.C. Oswald \& H.T. Lehmann. Saint Louis: Concordia. 
LUTHER, M. 1999 (c1967). [CE]: Luther's Works. Vol. 30: The Catholic epistles. Ed. by J.J. Pelikan, H.C. Oswald \& H.T. Lehmann. Saint Louis: Concordia.

LUTHER, M. 1999 (c1967). [CS(III)]: Luther's Works. Vol. 46: The Christian in society 3. Ed. by J.J. Pelikan, H.C. Oswald \& H.T. Lehmann. Saint Louis: Fortress. ([AP] Admonition to peace a reply to the twelve articles of the peasants in Swabia (1525), 1-43.)

LUTHER, M. 1999 (c1967). [TT]: Luther's Works. Vol. 54: Table talk. Ed. by J.J. Pelikan, H.C. Oswald \& H.T. Lehmann. Saint Louis: Fortress.

LUTHER, M. 1999 (c1968). [LG]: Luther's Works. Vol. 5: Lectures on Genesis: chapters 26-30 (1541). Ed. by J.J. Pelikan, H.C. Oswald \& H.T. Lehmann. Saint Louis: Concordia.

LUTHER, M. 1999 (c1970). [C\&M(I)]: Luther's Works. Vol. 39: Church and ministry 1. Ed. by J.J. Pelikan, H.C. Oswald \& H.T. Lehmann. Saint Louis: Fortress. ([SOB] A sermon on the ban (1520), 3-23; [DCM] A discussion on how confession should be made (1520), 23-47.)

LUTHER, M. 1999 (c1970). [C\&M(II)]: Luther's Works. Vol. 40: Church and ministry 2. Ed. by J.J. Pelikan, H.C. Oswald \& H.T. Lehmann. Saint Louis: Fortress. ([IPP] Instructions for the visitors of parish pastors in electoral saxony (1528), 262-320.)

LUTHER, M. 1999 (c1970). [LG]: Luther's Works. Vol. 6: Lectures on Genesis: chapters 31-37 (1542 et seq). Ed. by J.J. Pelikan, H.C. Oswald \& H.T. Lehmann. Saint Louis: Concordia.

LUTHER, M. 1999 (c1971). [CS(IV)]: Luther's Works Vol. 47: The Christian in society 4. Ed. by J.J. Pelikan, H.C. Oswald \& H.T. Lehmann. Saint Louis: Fortress. ([OJ] On the Jews and their lies (1543), 119-305.)

LUTHER, M. 1999 (c1972). [ESL \& S]: Luther's Works. Vol. 15: Ecclesiastes, Song of Solomon, last words of David, 2 Samuel 23:1-7. Ed. by J.J. Pelikan, H.C. Oswald \& H.T. Lehmann. Saint Louis: Concordia.

LUTHER, M. 1999 (c1972). [L(II)]: Luther's Works. Vol. 49: Letters 2. Ed. by J.J. Pelikan, H.C. Oswald \& H.T. Lehmann. Saint Louis: Fortress.

LUTHER, M. 1999 (c1972). [LR]: Luther's Works. Vol. 25: Lectures on Romans (1535). Ed. by J.J. Pelikan, H.C. Oswald \& H.T. Lehmann. Saint Louis: Concordia.

LUTHER, M. 1999 (c1973). [C\&T]: Luther's Works. Vol. 28: 1 Corinthians 15, Lectures on 1 Timothy. Ed. by J.J. Pelikan, H.C. Oswald \& H.T. Lehmann. Saint Louis: Concordia.

LUTHER, M. 1999 (c1973). [LMP (III)]: Luther's Works. Vol. 20: Minor prophets 3: Zechariah. Ed. by J.J. Pelikan, H.C. Oswald \& H.T. Lehmann. Saint Louis: Concordia.

LUTHER, M. 1999 (c1974). [LMP (II)]: Luther's Works. Vol. 19: Minor prophets 2: Jonah and Habakuk. Ed. by J.J. Pelikan, H.C. Oswald \& H.T. Lehmann. Saint Louis: Concordia.

LUTHER, M. 1999 (c1974). [S(II)]: Luther's Works. Vol. 52: Sermons 2. Ed. by J.J. Pelikan, H.C. Oswald \& H.T. Lehmann. Saint Louis: Fortress.

LUTHER, M. 1999 (c1975). [LMP (I)]: Luther's Works. Vol. 18: Minor prophets 1: Hosea-Malachi. Ed. by J.J. Pelikan, H.C. Oswald \& H.T. Lehmann. Saint Louis: Concordia.

MELANCHTHON, P. 1952. [MW] Melanchthon Werke: [LC]. 2. Band, 1. Teil: Loci Communes, (1521). Ed. by H. Engeland. Gütersloh: Bertelsman.

RAATH, A.W.G. 2006. The justness of love: the essence and status of justice in Luther's theology. Studia historiae ecclesisticae, 32(1):335-354. 
Key concepts:

natural law

property

right to property

Kernbegrippe:

eiendomsreg

natuurreg

reg op eiendom 
